\title{
Minimize the Material Handling Time of Agricultural Finished Goods
}

\author{
Dr. Karthikeyan $\mathrm{S}^{* a}$ \\ Associate Professor*a \\ Faculty of Mechanical Engineering \\ Thiagarajar college of Engineering, Madurai
}

\author{
Sundaramahalingam $\mathrm{S} * \mathrm{~b}$ \\ PG Student of Industrial Engineering*b \\ Department of Mechanical Engineering \\ Thiagarajar college of Engineering, Madurai
}

\begin{abstract}
Agriculture is the backbone of India. Nowadays, in agriculture facing many problems, so initial the project starts with the preparation of a questionnaire. According to the problem facing agriculture in Ayikudi village, It covers nearly 425 hectors of agricultural lands surrounded by it. From the questionnaire, the problem is identified in the field of material handling in which the raw materials, finished products like vegetables, coconut, banana, etc are difficult to transfers the products from the field to outside of the field, the project approaches to implement the slat chain conveyors system in the agriculture field to transfers the materials and products from the field to outside of the field, before the implementation of conveyor system in agricultural filed. The methodology, initial step is to defines about the agricultural field from the data gathered it leads to locate the conveyor at optimal point to cover all landholders, next step is to mathematical model is done, and next step is to design of conveyor is done, and next step is cost estimation for overall expenses is estimated for implementation and the final step is to simulation process for the manual and conveyor system implementation is done, it results that the time, cost and manpower reduce in the agriculture field is compared with manually carried by load carriers.
\end{abstract}

Index Terms-Conveyor system, Cost estimation, Material handling, Simulation

\section{INTRODUCTION}

The word 'Agriculture' is derived from the Latin word 'Agri' means Land or field and 'Culture' means cultivation. It means the science and art of producing crops and livestock for economic purpose. The history of dates back to Indus Valley Civilization and even before that in some places of Southern India. India ranks second worldwide in farm outputs. As per 2018, agriculture employed $50 \%$ of the Indian workforce and contributed $17-$ $18 \%$ to the country's GDP. In today's world where transportation is perhaps one of the most utmost elements for the business to succeed, people are always in search of better, faster and cost-effective techniques of transporting, tracking and processing their goods. In recent years, the conveyor belt system has emerged as one of the best ways of transporting the product. This system consists of two or more drums that are also referred to as pulleys with a conveyor belt i.e. he carrying medium and it rotates around the drums. The belt is propelled by one or two of the pulleys. The pulley that powers the belt is called the drive pulley and the other is called the idler pulley. The conveyor belt is categorized intotwo classes, one that transports general material and

the other that is responsible for taking agricultural material such as sand, ore, coal, salt, grain and much more from one place to another. Uses of conveyor in the agricultural community. The uses of a conveyor system agricultural community are numerous. It is used in the feeding process that processes or freezes vegetables, fruits, and other agricultural products for packing to be sent to the retailers or other process plants. Besides this, these belts are effectively being used for loading bulk quantities into trucks to get them transported to their final destination. Bean market is another place, where conveyor belt scales are used in a large number. Additionally, these belts are also to load out the soybeans into the trucks that carry them to the end process.

\section{LITERATURE REVIEW}

Saifallah Benjaafar al. [1] Discussed to minimize workin-process. It shows that the choice of layout has a direct impact on work-in-process accumulation, manufacturing lead time, achievable throughput rates, and required material handling capacity. It has two methodology sources: the processing departments and the material handling transporter. In both cases, WIP accumulation is determined by

- Variability in the arrival process.

- Variability processing/ transportation time.

- Utilization of the departments and the transporter.

The objective is to minimize work- in-process. the model to explore the relationship between layout configuration and operational performance. It showed that the conventional criterion of selecting layouts based on average material handling distances can be a poor indicator of queuing effect.

Zhang chunzhi al. [2] developed the dynamic model is based which can be used to researching the dynamic characteristic of the scraper conveyor sprocket transmission system described.

- Simulation operation mode approach

- It can offer a more veracious dynamic load.

- For sprocket tooth profile optimization, structural strength. evaluation and fatigue life prediction for key components and Traditional experiential method. It can operate securely in rated power output condition because the maximal contact force between chains is far less than a strength limit of chains. 
Valeria Borodin al. [3] discussed the comprised of (i) Agriculture itself;(ii) The supply industry, especially the chemical industry that provides inputs for agricultural production(iii) Food processing and trade;(iv) Retail as the final link with consumers, the ultimate customers of the food value chain. Deterministic based: uncertainties are defined by parameter domains in which they can vary by intervals (also called gray numbers) or crisp sets or believable. Deterministic-based, Probabilistic, Possibility. Approaches are stochastic programming, Robust programming, Simulation-based approach. it provides a structured overview of the recent use of operations research methodologies for handling uncertainties in the framework of agri-supply chain management. Operations research has a long tradition in improving quantitatively operations and supporting decisionmaking processes, able to manipulate with both deterministic and stochastic data.

Abhijit Gaikwad al. [4] developed the material handling equipment based on facilitate easy, cheap, fast and safe loading and unloading with least human interference. They approached design calculations and considerations of belt conveyor system for press machines, in terms of size, length, capacity and speed, roller diameter, power and tension, idler spacing, type of drive unit, diameter, location and arrangement of pulley, angle and axis of rotation, control mode, intended application, product to be handled as well as its maximum loading capacity in order ensure fast, continuous and efficient movement of material. the Conveyor Belt System for material handling improves the speed of material handling and the system reduces human effort. The workers are eliminated and ultimately the operation cost is reduced and profit gets increased.

Sheetal Roman al. [5] The conveyor is at a specific distance from floor level which runs at a very low speed so that it becomes convenient and flexible for the operator to assemble the vehicle parts while the conveyor is moving. Then the vehicle is manually unloaded at the last station. Conveyor Design Steps: Conveyor chain the following point should be considered. Chain design, Calculating Chain Pull Attachment, Coefficient of Friction, Service factor, attachments, finite element analysis, Testing, Inspection Function Testing, Load Testing. It argued that by integrating information technology with production processes many undesirable material handling activities could be easily avoided, also the companies would be able to attain increased space efficiency on the production/assembly area and decreased work in process.

Enkhbat Batbayar al. [6] discussed the performances of the agriculture manure spreader electrical control system.
It controlling the speed of the beaters and conveyor. The hydraulic control system consists of a Load sensor, Belt speed sensor, Hydraulic belt sensor motor, Gate height control follow (PTO) speed \& inductive sensor on the gate based on electronic \& automatic system. Method of controlling Conveyor speed with beater, Spreader velocity into the field, measuring weight meter using differential load cell. The main electrical control unit (client-side ECU) applications were developed.

\section{Observation from literature:}

From the collected literature, various factors were observed, they are:

- To improve the performances of the agriculture manure spreader electrical control system and by controlling the speed of the beaters, conveyor.

- Material handling equipment are designed on based that they facilitate easy, cheap, fast and safe loading and unloading with least human interference and the workers are eliminated and the ultimately the operation cost is reduced and profit get increased.

- The structured overview of the recent use of operations research methodologies for handling uncertainties in the framework of agri- supply chain management.

- The minimize work-in-process and the choice of layout has a direct impact on work-in-process accumulation, manufacturing lead time, achievable throughput rates, and required material handling capacity and the dynamic modeling of scraper chain conveyor and design and analysis of slat chain conveyor.

\section{PROBLEM DESCRIPTION}

\section{Problem identification:}

Most of the agriculture fields are covered or surrounded nearby.

- Particularly the problem has identified in Tenkasi district Ayikudi village nearly 425 hectors covers of agriculture field.

- In which cultivated grains, vegetables, coconut, fertilizers, etc are taken manually from their field to out of the field is difficult, excess of time and also less availability of workforce.

- So the farmers are facing problem to transmit the finished goods like tomato, onion, cotton, cholam, paddy Coconut etc. from one place to another.

- While the rainy season it's one of the major issues to transforms the load. 


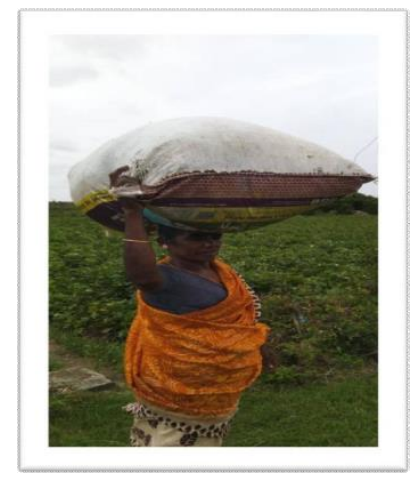

Fig .1: load carried by women Fig.2: load carried by men

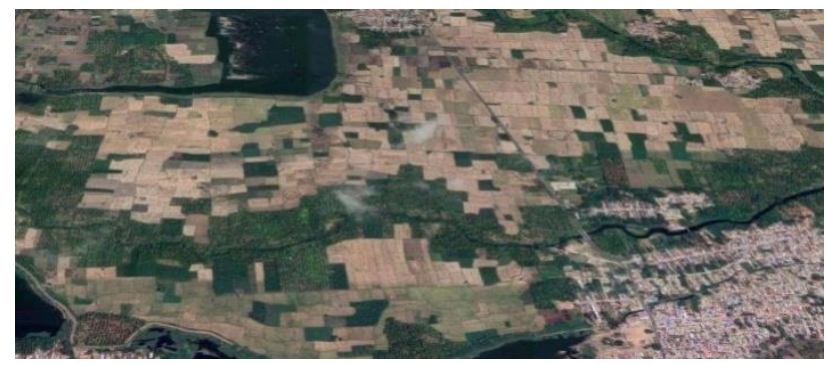

Fig 3: 3D view of agriculture field layout

Fig 4: Furrow Fig 5: Drains
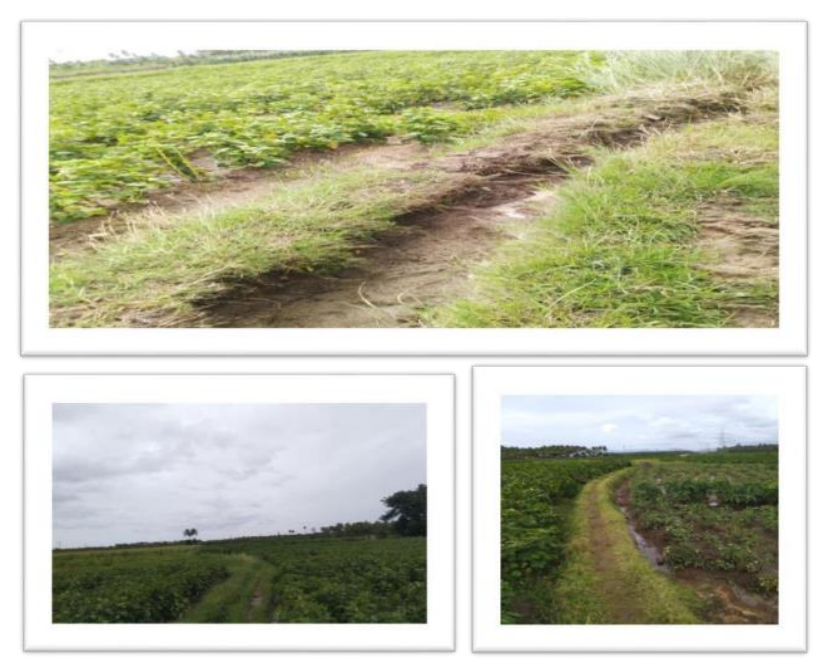

Table 1: Load carried by manually

\begin{tabular}{|l|c|c|c|c|c|}
\hline $\begin{array}{l}\text { No. of } \\
\text { Member to } \\
\text { carrying the } \\
\text { load }\end{array}$ & Load (Kgs) & Distance (m) & $\begin{array}{l}\text { Time(min) } \\
\text { Carrying } \\
\text { with load }\end{array}$ & $\begin{array}{l}\text { Returning } \\
\text { time to carry } \\
\text { Another load }\end{array}$ & Cost(Rs) \\
\hline \multirow{5}{*}{1} & 50 & 700 & 16 & - & 50 \\
\cline { 2 - 6 } & 50 & 700 & 18 & 10 & 50 \\
\cline { 2 - 6 } & 50 & 700 & 17 & 10 & 50 \\
\cline { 2 - 6 } & 50 & 700 & 17 & 11 & 50 \\
\hline \multirow{2}{*}{ Total } & 50 & 700 & 18 & 9 & 50 \\
\cline { 2 - 6 } & & $\mathbf{5 5 0 0}$ & $\mathbf{8 6}$ & $\mathbf{4 0}$ & $\mathbf{5 0 0}$ \\
\cline { 2 - 5 } & & & Total time & $\begin{array}{l}\mathbf{1 3 0} \text { mins } \\
(\mathbf{2 . 1 0} \text { hour) }\end{array}$ & \\
\hline
\end{tabular}

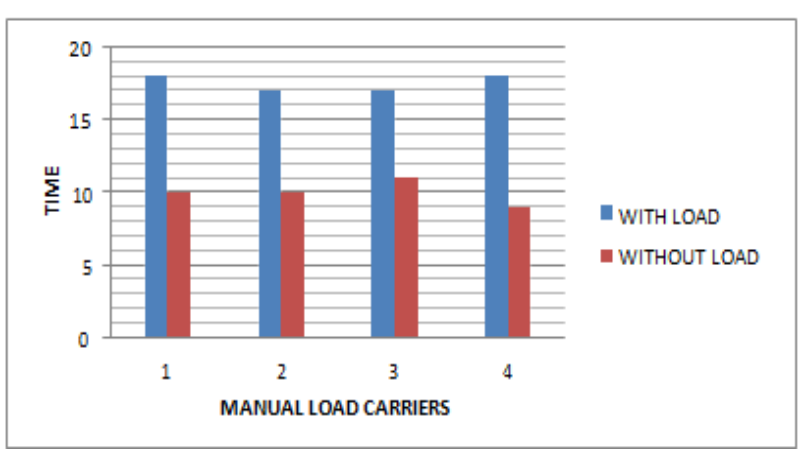

Fig 6: Graphical representation of manual load carriers

\section{Inference}

From this graph, it shows that the load carried by the carriers with the load and returning time of the carriers.

\section{Objective:}

To minimizes the material handling time in the agriculture field and financial estimation of the project.

\section{Problem solving approach}

Slat conveyors

A chain conveyor works on the principle of the interconnectivity of a chain connects each gear, resulting in a smooth carrying process. The chain conveyor has a series of gears connected into a continuous system by the chain. Typically, each gear has teeth that deliver a free rotational interface with the chain. A slat conveyor is a two-strand chain conveyor with slats connected to the chain and a guiding system for the slats. This creates a smooth surface to which tooling details or fixtures can be mounted to hold parts in the desired position. Slat Conveyors are used in horizontal conditions and operating at relatively slow speeds. They are generally used to move items that are not typically conveyable on rollers or belts, due to an irregular shape or bottom condition. So these approaches help to solve the problem of material handled in the agriculture field.

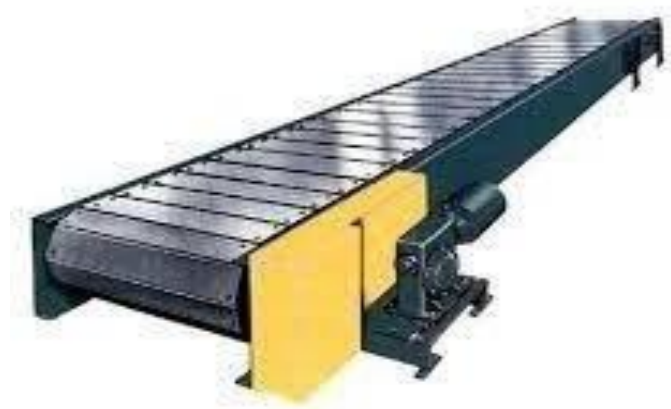

Fig 7: Model of Slat chain conveyor 


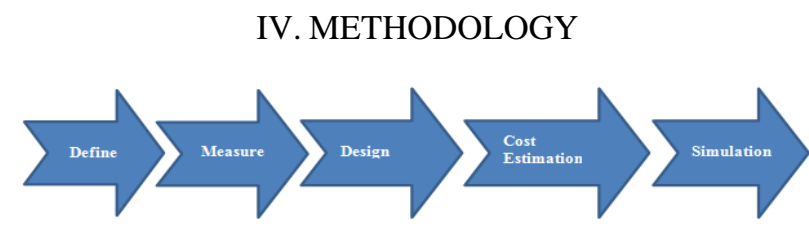

Define

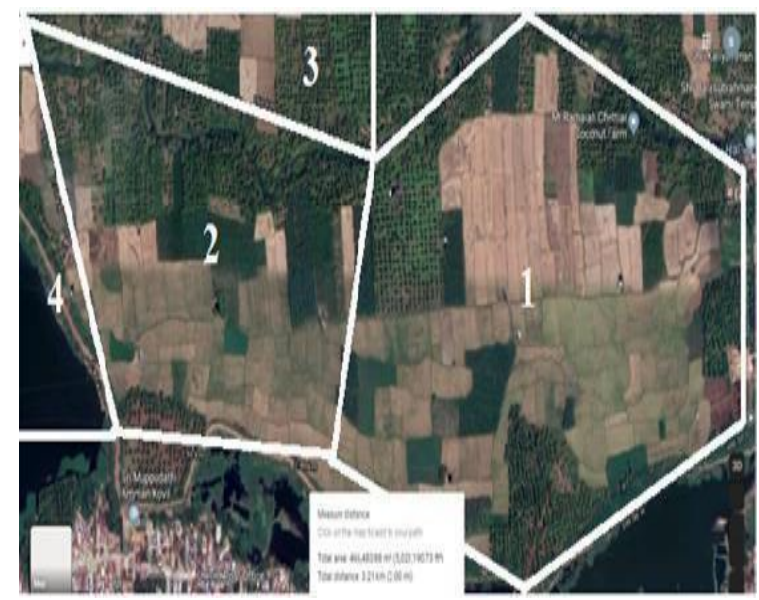

Fig 8: Area splitting into sections

\section{Inference:}

In the photographic view of the agriculture field, the total area looks to be in irregular shape and size, so it divided. According to shape is divided into the number of sections to find out the co-ordinates of the agriculture field.

\section{B.Measure Calculation:}

Table 2: Area measurement

\begin{tabular}{|l|l|l|}
\hline Area of sections $\left(\mathrm{m}^{2}\right)$ & \multicolumn{1}{|c|}{$X(\mathrm{~m})$} & \multicolumn{1}{|c|}{$Y(\mathrm{~m})$} \\
\hline Section Area $1: 302258$ & $X_{1}=450$ & $Y_{1}=280$ \\
\hline Section Area 2:157763 & $X_{2}=400$ & $Y_{2}=365$ \\
\hline Section Area 3: 27433 & $X_{3}=134$ & $Y_{3}=462$ \\
\hline Section Area 3: 24303 & $X_{4}=61.66$ & $Y_{4}=284$ \\
\hline
\end{tabular}

$$
\begin{aligned}
& \bar{X}=\left(\frac{A_{1} X_{1}+A_{2} X_{2} \cdot A_{3} X_{3} \cdot A_{4} X_{4}}{A 1+A_{2} \cdot A_{3} \cdot A_{4}}\right) \\
& \bar{X}=\left[\frac{(302258 * 450)+(157763 * 400) \cdot(27433 * 134)-(24303 * 61.66)}{(302258+157763.27433 .24303)}\right] \\
& \bar{X}=474.29 \mathrm{~m} \\
& \bar{Y}=\left(\frac{A_{1} Y_{1}+A_{2} Y_{2} \cdot A_{3} Y_{3} \cdot A_{4} Y_{4}}{A_{1}+A_{2} \cdot A_{3} \cdot A_{4}}\right) \\
& \bar{Y}=\left(\frac{(302258 * 280)+(157763 * 365)-(27433 * 462)-(24303 * 284)(302258+}{157763.27433 .24303)}\right) \\
& \bar{Y}=300 \mathrm{~m}
\end{aligned}
$$$$
\text { Google Maps aykuol }
$$

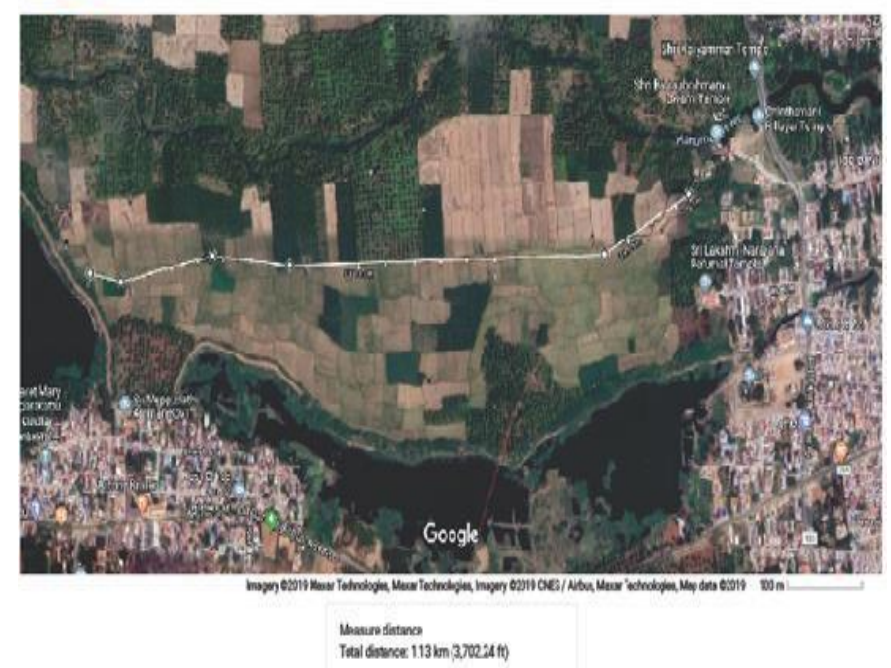

Fig 9: Implementing conveyor system in agriculture field

Inference

From point $\overline{\mathrm{x}}$ and $\overline{\mathrm{y}}$, the conveyor system is initiated to start the implement at the point. 


\section{Design}

\section{Basic Requirements}

To enable the most suitable chain to be selected for a particular application, it is necessary to know full application details such as the following:

- Type of conveyor.

- Conveyor centre distance and inclination from the horizontal.

- Type of chain attachment, spacing, and method of fixing to the chain.

- Number of chains and chain speed.

- Details of conveying attachments, e.g. weight of slats, buckets, etc.

- Description of material carried, i.e. weight, size, and quantity.

- Method of feed and rate of delivery.

Specifications

Table 3: Slat chain conveyor specification

\begin{tabular}{|l|l|}
\hline Chain pitch & $500 \mathrm{~mm}$ \\
\hline $\begin{array}{l}\text { Total load on slat } \\
\text { conveyor }\end{array}$ & $6000 \mathrm{~kg}$ \\
\hline Conveyor speed & 30 to $60 \mathrm{~m} / \mathrm{min}$ \\
\hline Conveyor sprocket & $200 \mathrm{~mm}$ pitch, 8 teeth. \\
\hline Idle slat thickness & $6 \mathrm{~mm}$ \\
\hline Load slat thickness & $8 \mathrm{~mm}$ \\
\hline Slat width & $500 \mathrm{~mm}$ \\
\hline Slat height & $600 \mathrm{~mm}$ above floor level (FFL $+600 \mathrm{~mm})$ \\
\hline Station pitch & $3000 \mathrm{~mm}$ \\
\hline
\end{tabular}

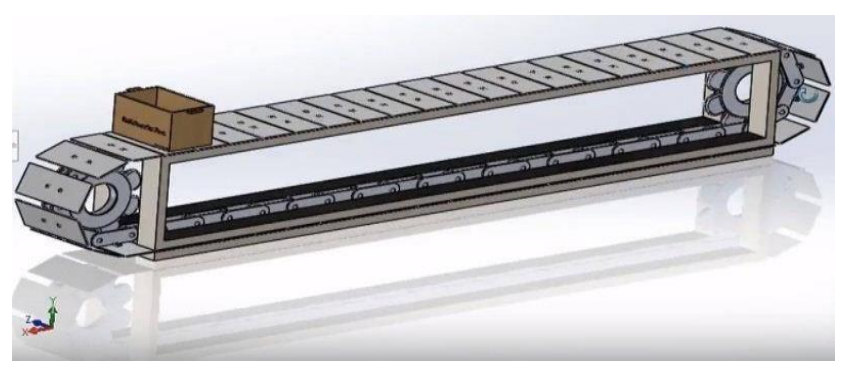

Fig 8: 3D model of slat chain conveyor

\section{Cost Estimation:}

Projects bring risks, and risks bring unexpected costs. Cost estimation is the process that takes those factors into account and calculates a budget that meets the financial commitment necessary for a successful project.

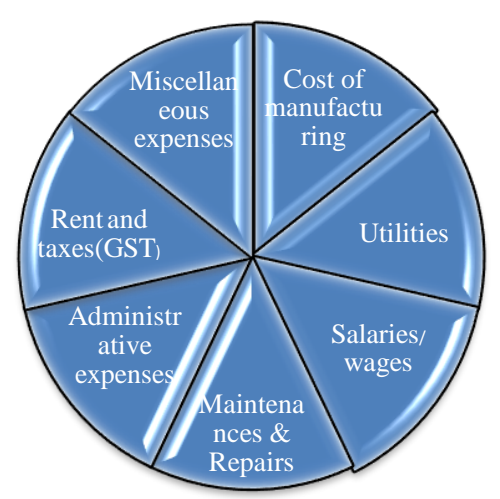

Fig 9: Contributing element for cost estimation

Table 4 : Financial cost expenses estimation for 5 years

\begin{tabular}{|c|c|c|c|c|c|c|}
\hline & \multirow[t]{2}{*}{ Praticular } & \multicolumn{5}{|c|}{$\operatorname{lmoun}\left(\mathrm{Rs}_{\mathrm{S}}\right)$} \\
\hline & & lyear & lyear & Jyear & 4jear & Syear" \\
\hline a. & $\begin{array}{l}\text { Costof } \\
\text { manuruturuming }\end{array}$ & $1,343,0,000$ & & & & \\
\hline$b_{1}$ & Collitites & $1,0,0,00$ & 10,000 & 10,000 & 10,000 & 10,000 \\
\hline a & Salaries lagege & $13,30,000$ & 60,000 & 65,00 & 6,000 & 67,300 \\
\hline d. & $\begin{array}{l}\text { Jaintenances \& } \\
\text { Repairs }\end{array}$ & $1,15,500$ & $1,1,5,000$ & $1,30,000$ & $1,45,000$ & $1,50,000$ \\
\hline h & \begin{tabular}{|l} 
Administratire \\
erpensuss
\end{tabular} & 20,000 & 22,000 & 24,000 & 26,000 & 28,000 \\
\hline t & $\begin{array}{l}\text { Rertand } \\
\text { tarese(GST) }\end{array}$ & 83,0,000 & 32,000 & 32,000 & 32,000 & 32,000 \\
\hline 8 & $\begin{array}{l}\text { lliscelaneous } \\
\text { erpensses }\end{array}$ & 10,000 & 8,00 & 7,00 & 6,000 & 6,000 \\
\hline h. & Trarelling erpensses & 85,00 & 2,000 & 3,000 & 4,00 & 5,000 \\
\hline i & $\begin{array}{l}\text { Total cost of } \\
\text { production }\end{array}$ & $1,9,9,0,0,00$ & 159,000 & 1,11,000 & 290,000 & 2098500 \\
\hline$j$ & $\begin{array}{l}\text { Fimancial } \\
\text { chargeres(intersest) }\end{array}$ & $12,0,0,00$ & $24,0,0,0$ & $36,0,0,00$ & \$8,0,0,000 & 720,0,00 \\
\hline ki. & Depreatition & $5,0,0,000$ & $5,20,000$ & $60,3,000$ & $7,3,0,00$ & $8,3,5,000$ \\
\hline & Iotal & $1,1,6,6,0,000$ & $31,9,900$ & $44,96,000$ & $88,0,000$ & $803,3,500$ \\
\hline & & & simation & jeans rith int & est mount & $\begin{array}{l}39,4,7,5,000 \\
\text { Crovers }\end{array}$ \\
\hline
\end{tabular}


Table 5: Project profitability analysis

\begin{tabular}{|l|l|l|}
\hline S.No & Description & Values(Rs.) \\
\hline a & $\begin{array}{l}\text { Manufacturing Expenses (Raw materials } \\
\text { +Utilitiest salaries wages) }\end{array}$ & $148,72,000$ \\
\hline b & Administrative expenses & 20,000 \\
\hline c & Interest & $12,00,000$ \\
\hline d & Depreciation & $5,00,000$ \\
\hline e & Gross Profit & $1,65,92,000$ \\
\hline f & Income Tax & $8,30,000$ \\
\hline g & Netprofit & $1,57,62,000$ \\
\hline
\end{tabular}

Return on Investment:

Return on investment (ROI) estimates the gain or loss generated on an investment relative to the amount of money invested. ROI is usually formulated as a percentage and is typically used for personal financial decisions, to compare a company's profitability or to compare the efficiency of different investments.

Table 6: Return on investment is calculated

\begin{tabular}{|c|c|}
\hline $\begin{array}{l}\text { Cost of implementation of conresor in agriculture field } 850 \text { meters } \\
\text { (initial set-up cost) }\end{array}$ & $1,05,72,0000$ \\
\hline Cost of per meter implementation & $15,800 \mathrm{Rs}$ \\
\hline . Yo of landholder in 425 hector & 123 \\
\hline Each load carriers carries the load & $500 \mathrm{kgg}$ \\
\hline Cost of each 50 kgof load & 50 \\
\hline $\begin{array}{l}\text { Each wreek yiedd takes place by each landholders in period of } \\
\text { (march to october') ereery yeal. }\end{array}$ & 2 times \\
\hline So, of landholders take rield per' week & 221 \\
\hline Estimated cost spend by landholders for load carrying per' reek & $1,22,500$ \\
\hline Estimated cost of load carried per month & $4,90,000 \mathrm{Rs}$ \\
\hline Estimated cost of duration for" 7 month & $34,30,000 \mathrm{Rs}$ \\
\hline Estimated cost of total inrestment for years & $1,71,50,000 R$ \\
\hline Estimated cost for '̧ y̧ears & $3,94,78,500 R$ \\
\hline Estimated net profit & $1,57,02,000 \mathrm{Rs}$ \\
\hline Estimated after' years net profit $(1,71,50,000-1,60,72,000)$ & $\int, 78,000 \mathrm{RS}$ \\
\hline Estimated retulu on inrestment in percentage & $39,92 \%$ \\
\hline
\end{tabular}

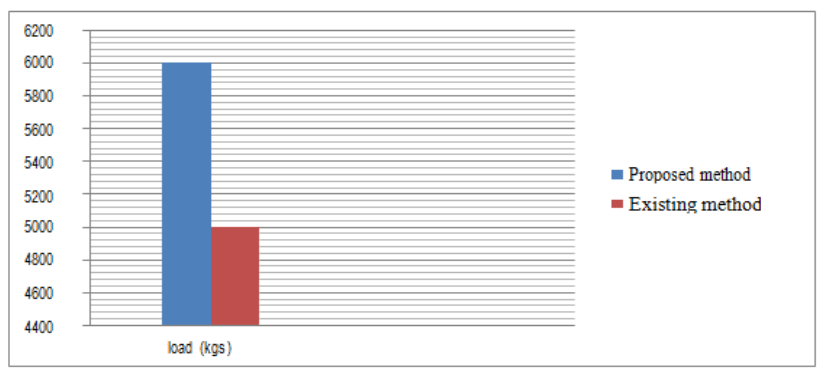

\section{E. Simulation}

Flexsim software is used to simulate the load carried by manual and conveyor system used in the agricultural field.

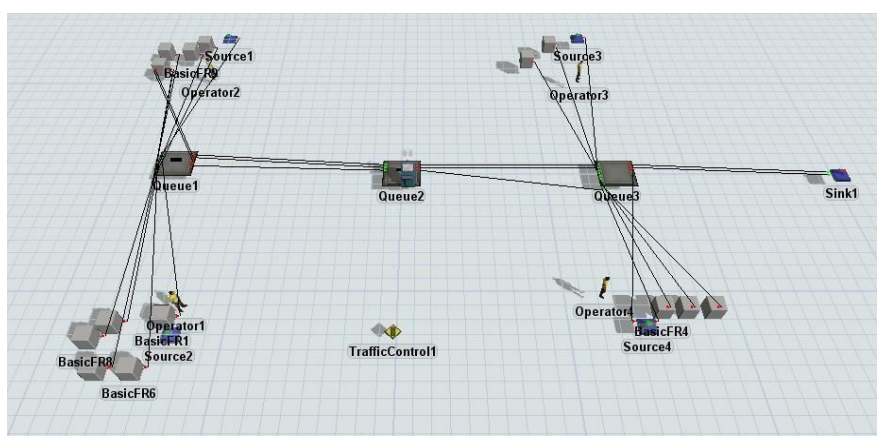

Fig 10: Load carried by load carriers is simulated by flexsim

\section{Inference:}

It shows that the load carried by manual process simulated in the flexsim software.

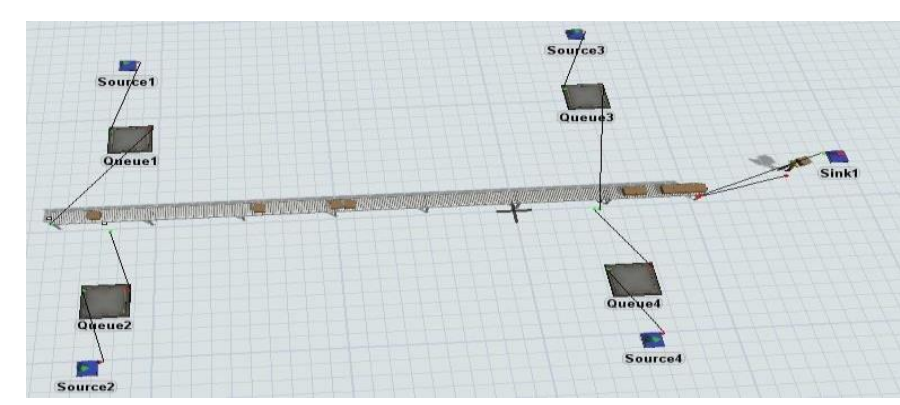

Fig 11: Load carried by conveyor system

Inference:

It shows that the implementation of conveyor in the agriculture is simulated by flexsim software.

Results:

Fig 11: Loads carried by manual and by conveyor system Inference:

This graph compares the load carried by load carriers as an existing method and the implementation of the conveyor system as a proposed method. 


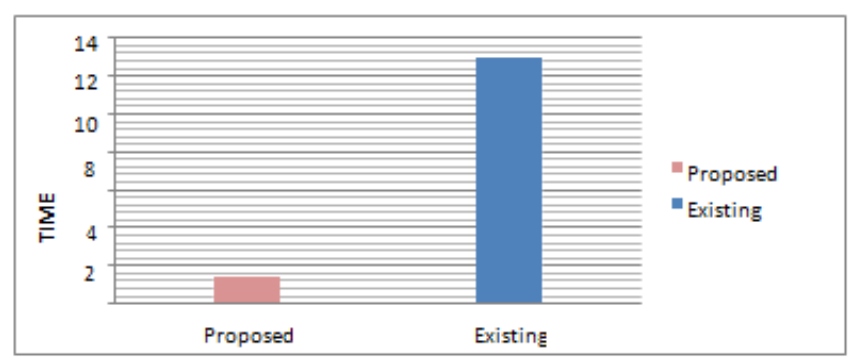

Fig 12: Time is compared with both existing and proposed method.

\section{Inference:}

This graph shows the time to carry the load manually as the existing method and proposed method as implementing the material handling conveyor system in the agricultural field.

Present method:

Table 7: Cost of load carried by manual

\begin{tabular}{|l|l|}
\hline Average working load carriers & 18 \\
\hline $\begin{array}{l}\text { Average cost spend per day for } \\
\text { load carriers(wages) }\end{array}$ & 900 \\
\hline Working period per year & 7 months \\
\hline $\begin{array}{l}\text { Total Cost spend for load } \\
\text { carriers per year }\end{array}$ & $34,30,000$ \\
\hline
\end{tabular}

Proposed method:

Table 8: Cost of implementing conveyor system

\begin{tabular}{|l|l|}
\hline Initial setup- cost & $1,34,30,000$ \\
\hline $\begin{array}{l}\text { Operating cost per year(electrical } \\
\text { consumption) }\end{array}$ & $4,00,000$ \\
\hline Maintanence cost per year & $6,25,000$ \\
\hline Total cost per year & $10,25,000$ \\
\hline Cost of saving & $\mathbf{2 4 , 0 5 , 0 0 0}$ \\
\hline
\end{tabular}

\section{CONCULSION}

This project, it shows about the time taken by manually the load carried by load carriers in the agricultural field is analyzed and by implementing the material handling conveyor system in the field, it leads to reduces the time, cost and man-power.

Scope and future works

This project leads to move towards the future work as the Design and Modeling of a portable conveyor system to the agricultural field. The conveyor system which will fold one another moves with the help mechanized vehicle.

It may handle at the outside of the agricultural field. The feeder (conveyor) will move into the agricultural field from which the material will transmit. The feeder conveyor mechanized vehicle will cover the nearby all villages.

\section{REFERENCES}

[1] Saifallah Benjaafar, (1998)."Design of Manufacturing Plant Layouts with Queuing Effects", PP 260-265.

[2] Zhang chunzhi, Meng guoying,(2016) "Dynamic modeling of scraper conveyor sprocket transmission system and simulation analysis",PP 1390-1394.

[3] Valeria Borodin, Jean Bourtembourg, Faicel Hnaien, Nacima Labadie, (2016)"Handling uncertainty in agricultural supply chain management",European Journal of Operational Research 254 ,PP 348-359.

[4] Abhijit Gaikwad,Yogesh Raut, Jitendra Desale, Akshay Palhe , Govinda Shelar, Prof.Shreekant Pawar , (2017)" Design and Development of Automated Conveyor System for Material Handling", IOSR Journal of Mechanical and Civil Engineering (IOSR-JMCE) e-ISSN: 2278-1684,ISSN: 2320-334X, PP 31- 34.

[5] SheetalRoman,Mokshada,Wankhede,Anushree,Gudalkar,Prajakta Kadam Adwant Amruta" (2017) Design and Analysis of Slat Conveyor". (ICIIIME), ISSN: 2321-8169, PP Volume: 5 Issue: 6 $1496-1504$.

[6] Enkhbat Batbayar ,Kim Sion, Munkhtamir Oyumaa ,Woonchul Ham, Enkhbaatar Tumenjargal, Sodbileg Tsogt-Ochir, (2019) "Study and Implementation of the Manure Spreader Machine Control System", (IWED) 978-1-5386-9453-4. 